\title{
Domestic Violence against Women in Indonesia: The Recent Domestic Violence Elimination Law Analysis
}

\author{
Mahfud $^{1}$, Rizanizarli \\ ${ }^{1}$ Universitas Syiah Kuala, Indonesia, \\ E-mail: mahfud_jufri@unsyiah.ac.id \\ ${ }^{2}$ Universitas Syiah Kuala, Indonesia, \\ E-mail:rizanizarli@unsyiah.ac.id
}

Submitted: April 22, 2021; Reviewed: May 24, 2021; Accepted: May 28, 2021

\section{Article Info}

\section{Abstract}

Keywords:
Domestic, violence, women,
Indonesia, Elimination.

DOI:

10.25041/fiatjustisia.v15no4.2276
Even though Law Number 23 of 2004 concerning on the Elimination of Domestic Violence was promulgated fifteen years ago, the number of domestic violence against women has not significantly decreased. The Law has not set concrete actions that may fall under the domestic violence that can be punished, particularly in terms of sexual abuse psychological violence, and negligence in household towards women. This research aims to analyze domestic violence against women in this Law and the conducts that are considered to be domestic violence which is commonly found in daily life in Indonesia. A purely qualitative research method encompassing document analysis of key documents in Indonesia and the Anti-Domestic Violence Law 2004 is adopted in this paper. The research reveals that This Law is particularly protecting women from household violence in Indonesia. The law has recognized physical violence, sexual violence, psychological violence, and negligence as sorts of domestic violence against women in household although it might find difficult to enforce the law when dealing with marital rape regarding lack of reports from victims and polygamy concerning circumstances that can be used to criminalize the perpetrators.

\section{A. Introduction}

The recent response of criminal law to domestic violence against women has been criticized as in the past it was considered as domestic matters banning a state from intervening it. The domestic violence practice is not 
only a breach of international law such as the United Nations on the Convention on the Elimination of All Forms of Discrimination against Women (hereinafter CEDAW), but also it is a violation of a state's criminal law. ${ }^{1}$ Criminalizing domestic violence is an important step taken by a state to show that the violence is also similar to other crimes. Incorporating domestic violence into a state's criminal legal system is believed to be able to protect a victim of domestic violence. ${ }^{2}$

The CEDAW Convention has not mentioned clearly about domestic violence until its Committee issued a substantial General Recommendation in 1992 interpreting the CEDAW as banning violence against women not only in public context but also in a private context. ${ }^{3}$ However, there is a very complete framework encompassing the abuse against women that can be found in Article 1 of the Convention. Article 1 of the Convention defines the violence against women as every distinction, restriction, or exclusion, created on the sex basis aiming at impairing or abolishing the recognition, exercise, or enjoyment by women, disrespect of their marital status on the basis men and women's equality, human rights and fundamental independence of civil, cultural, social, economic or in the other field. ${ }^{4}$ The latest international law on this issue, the Istanbul Convention 2011, defines domestic violence The Domestic Violence can be generally defined as each conduct containing violent, abusive, or hostile actions against adults who are linked to families or relatives. ${ }^{5}$ In addition, violence is described as an abusive behavior pattern committed either in family, dating, friends, and cohabitations. ${ }^{6}$

Indonesia has incorporated domestic violence against women into the Indonesian Penal Code (Kitab Undang-Undang Hukum Pidana) as general criminal law and Law Number 23 of 2004 concerning on Elimination of Domestic Violence (hereinafter the Domestic Violence Elimination Law) as a specific law in this matter. The reason for proposing the Domestic Violence Elimination Law, recent law regulating domestic violence against

\footnotetext{
${ }^{1}$ Ronagh JA McQuigg, Ronagh JAMcQuigg, "Domestic Violence as a Human Rights Issue: Rumor v. Italy," European Journal of International Law 26, no. 4 (2015): 1009-25, https://doi.org/10.1093/ejil/chv057.

${ }^{2}$ Leigh S. Goodmark, "Should Domestic Violence Be Decriminalized?," Harvard Journal of Law \& Gender 40, no. 15 (2017): 53-113.

${ }^{3}$ McQuigg, Ronagh JAMcQuigg, "Domestic Violence as a Human Rights Issue: Rumor v. Italy."

${ }^{4}$ Dubravka Šimonović, "Global and Regional Standards on Violence Against Women: The Evolution and Synergy of the CEDAW and Istanbul Conventions," Human Rights Quarterly 26, no. 3 (2014): 590-606, http://www.jstor.org/stable/24518259.

${ }^{5}$ Rajesh Sagar and Gagan Hans, "Domestic Violence and Mental Health," Journal of Mental Health and Human Behaviour 23, no. 1 (2018): 2-3, https://doi.org/10.4103/09718990.244924.

${ }^{6}$ Babette C. Drijber, Udo JL Reijnders, and Manon Ceelen, "Male Victims of Domestic Violence," Journal of Family Violence 28, no. 2 (2013): 173-78, https://doi.org/10.1007/s10896-012-9482-9. 
women in Indonesia because the former law, the Indonesia Penal Code, is considered to be unable to protect the victim of domestic violence in Indonesia. The Domestic Violence Elimination Law states that domestic violence is any conduct against a woman and other sub-ordinary groups resulting in or being likely to cause physical, sexual, economic, and or mental miseries or sufferings, without exception of threats, coercion, or indiscriminate liberty deprivation in the ambit of the household. ${ }^{7}$ Therefore, the Law limits domestic violence as criminal conduct to physical, emotional, sexual, and economic abuses.

Lily Zakiah Munir has discussed figh to understand the basis of theological violence against women in households in Indonesia. ${ }^{8}$ Elli Nur Hayati has looked into the sociocultural perspective impacts, which copes with dynamic women domestic violence survivors in a rural area of Purworejo. ${ }^{9}$ Siti Aisyah and Lyn Parker have discussed the experience of women suffered from domestic violence in Makassar, South Sulawesi that concludes that as an imbalance power of relationship that husband may legitimately have power over wives. ${ }^{10}$ Bennet et.al has discussed the definitions of domestic violence in the social perspective in Nusa Tenggara Barat, which concluded that violence exists in the communities and the domestic violence is considered as the private realm violence, not the public matter. ${ }^{11}$ Afrianty has discussed one of the women's organization works in organizing its resource to represent, help, and respond to the needs of women who are victims of domestic violence. ${ }^{12}$

The previous researchers have analyzed domestic violence in Indonesia from theological and social perspectives. However, an analysis on the recent Indonesian domestic violence legislation under Law Number 23 of 2004 concerning on the Domestic Violence Elimination Law, and whether the laws deemed as domestic violence from either physical, sexual, psychological, and household negligence have not been deeply discussed

\footnotetext{
${ }^{7}$ Lily Zakiyah Munir, "Domestic Violence in Indonesia," Muslim World Journal of Human Rights 2, no. 1 (2005): 1-37, https://doi.org/10.2202/1554-4419.1031.

${ }^{8}$ Munir.

${ }^{9}$ Elli Nur Hayati et al., "Elastic Band Strategy': Women's Lived Experience of Coping with Domestic Violence in Rural Indonesia," Global Health Action 6, no. 1 (2013): 1-12, https://doi.org/10.3402/gha.v6i0.18894.

10 Siti Aisyah and Lyn Parker, "Problematic Conjugations: Women's Agency, Marriage and Domestic Violence in Indonesia," Asian Studies Review 38, no. 2 (2014): 205-23, https://doi.org/10.1080/10357823.2014.899312.

${ }^{11}$ Linda R. Bennett, Sari Andajani-Sutjahjo, and Nurul I. Idrus, "Domestic Violence in Nusa Tenggara Barat, Indonesia: Married Women's Definitions and Experiences of Violence in the Home," The Asia Pacific Journal of Anthropology 12, no. 2 (2011): 146-63, https://doi.org/10.1080/14442213.2010.547514.

12 Dina Afrianty, “Agents for Change: Local Women's Organizations and Domestic Violence in Indonesia," Bijdragen Tot de Taal-Land-En Volkenkunde / Journal of the Humanities and Social Sciences of Southeast Asia and Oceania 174, no. 1 (2018): 24-46, https://doi.org/10.1163/22134379-17401024.
} 
yet. This paper aims to analyze the recent legislation on domestic violence against women in Indonesia based on Law Number 23 of 2004 concerning on the Domestic Violence Elimination Law and the interpretation of the forms of domestic violence against women in Indonesia. This paper will contribute to a better understanding of the national anti-domestic violence law concerning violence in households against women as although it has been introduced fifteen years ago, the violence against women in the household remains unreported as well as the number of domestic violence has not vanished yet in this country. It is expected that it will also contribute to how to develop more concrete domestic violence that must not be violated by a man towards a woman in the sphere of a private matter.

In identifying the objectives aforementioned, this paper will adopt a purely qualitative research method encompassing document analysis of key documents in Indonesia and the Anti-Domestic Violence Law 2004.

\section{B. Discussion}

\section{Domestic Violence Against Women Under the Law Number 23 of 2004 concerning on Domestic Violence Elimination Law}

The violence against women in a household has been declared a state problem. The Indonesian government introduced Law Number 23 of 2004 concerning on Domestic Violence Elimination Law as the government's response through criminal law approach in dealing with the violence committed in the household. ${ }^{13}$ The Law has fulfilled the need for a special law penalizing violence against women in the household. ${ }^{14}$ The promulgation of the Domestic Violence Elimination Law results from the ratification of the CEDAW Convention by Law Number 7 of 1984 concerning on the Ratification of the Convention on the Elimination of All Forms of Discrimination against Women. ${ }^{15}$ The passing of the Law is to abolish domestic violence in Indonesia. In addition, the introduction of the Domestic Violence Elimination Law becomes the milestone of protecting those who are victims of violence happening in the household in Indonesia. ${ }^{16}$ Moreover, the Indonesian policy of Zero Tolerance on Violence against Women is also a reason for the promulgation of the Domestic Violence

\footnotetext{
${ }^{13}$ Nur Hayati et al., "Elastic Band Strategy': Women's Lived Experience of Coping with Domestic Violence in Rural Indonesia."

${ }^{14}$ Munir, "Domestic Violence in Indonesia."

${ }^{15}$ Ani Purwanti and Fajar Ahmad Setiawan, "The State of Policy of Anti Domestic Violence During Covid-19 Pandemic in Indonesia," Brawijaya Law Journal: Journal of Legal Studies 7, no. 2 (2020): 238-54, https://doi.org/10.21776/ub.blj.2020.007.02.07.

${ }^{16}$ Roswita Sitompul, Alesyanti, and Muhammad Ridwan, "Domestic Violence as Initiated by Batak Culture in East Medan, Indonesia," Journal of Human Behavior in the Social Environment 30, no. 7 (2020): 835-42, https://doi.org/10.1080/10911359.2020.1750526. 
Elimination Law. ${ }^{17}$ Even though it has been taking in force since September 22,2004 , household violence reports from officials and its prosecution in the courts remain low and there is inadequate safe accommodation for women who are victims of domestic violence as well as a lack of centers for integrated rape crisis in Indonesia. ${ }^{18}$

According to Article 1 of the Domestic Violence Elimination Law, the meaning of domestic violence is any law against women, particularly which brings about misery or physical, sexual, psychological suffering, and/or family negligence including threats to illegally commit, force, or take freedom over within the ambit of the household. It is clear that Law Number 23, 2004 defines domestic violence as an inclusive law against anybody, particularly women, causing sexual, economic, physical, or psychological suffering and/or household negligence including intimidations of committing laws, forcing or limiting freedom in a manner violating the law within the context of the household. ${ }^{19}$ The definition provided in Article 1 above has criminalized laws that are not acknowledged as criminal laws in the Indonesian Penal Code (Kitab Undang-undang Hukum Pidana) as the general Criminal Legislation in Indonesia. It can be said that the Domestic Violence Elimination Law 2004 has been responsive to existing sorts of domestic violence committed in Indonesia which is not only punishing the laws of harming women's bodies as physical abuses, but also it is taking into consideration the mental and financial effects. The Law does not only protects women in the household but also men and anyone who has a familial kinship for instances: marriage, blood, a caring relationship, suckling at the same breast, and guardianship with husbands, wives, and children or anyone who work to assist the household and stay in the household. Interestingly, men may also be the victims of domestic violence. Somehow, it is unprecedentedly, one of the biggest achievements made under this Law is that housemaids (mostly women) who are prone to domestic violence have been put under protection by this Law although there is no legislation made yet to protect them from overworking and not humane working environments. ${ }^{20}$ Nevertheless, one of the most intransigent difficulties is the norm that conflict in the household is a private matter. ${ }^{21}$

\footnotetext{
${ }^{17}$ Elli Nur Hayati, Maria Emmelin, and Malin Eriksson, "Challenges for a Local Service Agency to Address Domestic Violence-A Case Study from Rural Indonesia," Global Journal of Health Science 6, no. 6 (2014): 214-25, https://doi.org/10.5539/gjhs.v6n5p214.

18 Bennett, Andajani-Sutjahjo, and Idrus, "Domestic Violence in Nusa Tenggara Barat, Indonesia: Married Women's Definitions and Experiences of Violence in the Home."

${ }^{19}$ Aisyah and Parker, "Problematic Conjugations: Women's Agency, Marriage and Domestic Violence in Indonesia."

${ }^{20}$ Alfitri Alfitri, "Protecting Women from Domestic Violence: Islam, Family Law, and the State in Indonesia," Studia Islamika 27, no. 2 (2020): 273-307, https://doi.org/10.36712/sdi.v27i2.9408.

21 Aisyah and Parker, "Problematic Conjugations: Women's Agency, Marriage and Domestic Violence in Indonesia."
} 
Article 5 of the Domestic Violence Elimination Law, regulates that anyone is prohibited to commit domestic violence within his/her household through physical, psychological, sexual abuses, or neglect of household. In addition, Article 6 of the Domestic Violence Elimination Law states that the physical abuse law is a law that causes suffering or serious wound. Articles 7, 8, and 9 of the Domestic Violence Elimination Law, consecutively define psychological violence as any law resulting in fear of confidence loss, controversially, sexual violence includes marital rape as one of the sexual violence laws and the violence of economy encompasses failing to provide financial support. ${ }^{22}$ The forms of violence against women in a household that are also known as intimate partner violence are sexual violence, physical attack, intimidation, threats, and financial deprivation are. ${ }^{23}$

\section{The Forms of Domestic Violence against Women in the Law Number 23 of 2004 concerning on Domestic Violence Elimination Law}

\section{a. Physical Violence}

The form of physical violence was the highest number of domestic violence in 2014 with the total cases was $3410 .{ }^{24}$ In 2020, there are 11.105 cases of domestic violence in Indonesia and physical violence is the highest number compared to other forms of domestic violence with a total number is 4.783. Domestic violence against wives has a percentage of 59\% from the total number of domestic violence..$^{25}$ Article 44 (1) has criminalized the perpetrator of domestic violence against women by maximal imprisonment of 5 years or fine of Rp.15.000.000,-. In addition, Article 44 (2), if the commission mentioned in Article 44 (1) causes a serious wound, the imprisonment can be maximal of 10 years or a fine of Rp. 30.000.000,- and if the commission in Article 44 (2) results in death, the maximal imprisonment is 15 years or a fine of Rp.45.000.000,-. Moreover, Article 44 (4) has clearly stated that if a husband physically abuses a wife without causing any serious injury, the total imprisonment may be sentenced is 4 months or a maximum fine of Rp. 5.000.000. Article 44 (4) is regulating the

\footnotetext{
${ }^{22}$ Philippa Venning, "Marrying Contested Approaches: Empowerment and the Imposition of International Principles: Domestic Violence Case Resolution in Indonesia," The Journal of Development Studies 46, no. 3 (2010): https://doi.org/10.1080/00220380903002913.

${ }^{23}$ I Gusti Ngurah Edi Putra, Putu Erma Pradnyani, and Ni Wayan Putri Larassita Parwangsa, "Vulnerability to Domestic Physical Violence among Married Women in Indonesia," Journal of Health Research 33, no. 2 (2019): 90-105, https://doi.org/10.1108/JHR-06-2018-0018.

${ }^{24}$ Nur Rofiah, "Kekerasan Dalam Rumah Tangga Dalam Perspektif Islam," Wawasan: Jurnal Ilmiah Agama Dan Sosial Budaya 2, no. 1 (2017): 31-44, https://doi.org/10.15575/jw.v2i1.829.

${ }^{25}$ Komisi Nasional Anti Kekerasan Terhadap Perempuan, "Instrumen Pemantauan Monev," Komnas Perempuan, 2021, https://komnasperempuan.go.id/instrumen-pemantauanmonevdetail/menemukenali-kekerasan-dalam-rumah-tangga-kdrt. 
woman as having a marital relationship with the perpetrator, her husband. It is different from what Article 44 (1), (2), and (3) rules; the women are out of wedlock relationship. Theoretically, physical violence may be in physical persecution form for instance; kicked, hit, slapped, etc. although this Law does not limit its protection to women, this Law avails hope for women to protect themselves, particularly those who have positions as wives. ${ }^{26}$ Physical violence amongst married women is one of the domestic violence sorts that may endanger women's health such as sexual contagious infections, termination of pregnancy, the increase of child mortality, and low weight of a new baby born. ${ }^{27}$

\section{b. Psychological Violence}

Concerning, mental or psychological violence, Article 45 (1) of the Domestic Violence Elimination Law, provides that for anyone who commits mental violence in a household, the maximal imprisonment that can be imposed is 3 years imprisonment, or the maximum fine is Rp. 9.000.000. In addition, if the perpetrator is a husband, the maximum of imprisonment is 4 months or the maximum fine is Rp. 3.000.000. Moreover, Article 45 (2) regulates that if the perpetration mentioned in Article 45 (1) committed by a husband towards a wife without causing serious suffering that can obstruct a wife from doing a daily job, the maximum penalty of imprisonment can be imposed is 4 months or the maximum of fine imposed is Rp. 3.000.000.

One study discussing the causes of psychological violence committed by husbands towards wives are being disloyal, drinking alcohol, fighting with other males, and witnessing domestic violence as a kid. The Domestic Violence Elimination Law has not elaborated what concrete actions can be interpreted as psychological violence. However, the previous study has described that insufficient economic support for the household by husbands is one of the psychological violence forms that can be punished under this Law. ${ }^{28}$

Surprisingly, a study looking at the relationship between polygamous marriage and physical violence in households shows that there is a strong relationship between polygamous marriage and women's suffering. This interpretation has resulted from the definition provided in the Domestic Violence Elimination Law, which defines laws causing psychological or sexual misery as domestic violence. Nevertheless, the study is not claiming that the Indonesian Government accepts domestic violence against women

\footnotetext{
${ }^{26}$ Hanafi Arief, "Legal Protection Against Women Victims by The Indonesian Domestic Violence Act 23, 2004," Sriwijaya Law Review 1, no. 1 (2017): 110-21, https://doi.org/10.28946/slrev.Vol1.Iss1.12.pp110-121.

27 Putra, Pradnyani, and Parwangsa, "Vulnerability to Domestic Physical Violence among Married Women in Indonesia."

${ }^{28}$ Nur Hayati et al., "Elastic Band Strategy': Women's Lived Experience of Coping with Domestic Violence in Rural Indonesia."
} 
because Law Number 1 of 1974 concerning on Marriage recognizes the polygamous marriage. In addition, arranged marriage that is resulting in the restriction of a wife to socialize with a husband's family with a threat of being killed if a wife ignores the husband order is also perceived as psychological violence. ${ }^{29}$

\section{c. Sexual Violence}

In addition, in terms of sexual violence law committed towards women in the household, Article 46 of the Law provides that a maximum penalty of 12 years' imprisonment or a maximum penalty of Rp. 36.000 .000 of fine. Sexual violence that is committed is in the form of marital rape and incest, but there is a report that incest has the highest number of sexual violence forms with a total is 822 cases in $2020 .{ }^{30}$ One study claims that marital rape is one of the forms of violence committed by a husband. ${ }^{31}$ In addition, marital rape is also defined as "unwanted intercourse by a man with his wife obtained by fore, threat of force or physical violence or when she is unable to give consent". The rape had not been a criminal law before the promulgation of this Law. Article 285 of the Indonesian Penal Code (Kitab Undang-undang Hukum Pidana) defines rape as a crime committed outside the marriage relationship between a man and a woman. ${ }^{32}$

Therefore, the recent Law of Domestic Violence Elimination criminalizing marital rape is an unprecedented law. However, the Islamic perspective on marital rape is different from what has been legislated in Article 46 of the Domestic Violence Elimination Law. In its teaching, marital rape does not exist since the husband is assured with his obligation to treat his wife well-meaning that the husband is compulsory to serve his wife's sexual desire but he is not suggested to force his wife to serve him if his wife has no willing to do it. ${ }^{33} \mathrm{~A}$ study shows that marital rape happens when there is a lack of awareness between a husband and a wife that in Islamic teaching, a woman also has a right to exercise sexual consent and to reject sex with her husband. ${ }^{34}$ It is clear that Islamic teaching prohibits a husband from committing sexual violence against a wife, but if a husband ignores his obligation to treat his wife gently, the wife the right to divorce

\footnotetext{
${ }^{29}$ Aisyah and Parker, "Problematic Conjugations: Women's Agency, Marriage and Domestic Violence in Indonesia."

${ }^{30}$ Perempuan, "Instrumen Pemantauan Monev."

${ }^{31}$ Leah Riggins, "Criminalizing Marital Rape in Indonesia," Boston College Third World Law Journal 24, no. 2 (2004): 421-26, https://lawdigitalcommons.bc.edu/twlj/vol24/iss2/6.

32 Muhammad Endriyo Susila, "Islamic Perspective on Marital Rape," Jurnal Media Hukum 20, no. 2 (2013): 317-32, https://journal.umy.ac.id/index.php/jmh/article/view/271.

${ }^{33}$ Susila.

${ }^{34}$ Bennett, Andajani-Sutjahjo, and Idrus, "Domestic Violence in Nusa Tenggara Barat, Indonesia: Married Women's Definitions and Experiences of Violence in the Home." 
the husband. ${ }^{35}$ Besides, marital rape, as a sexual violence form in domestic violence, for some women polygamy is also perceived as sexual violence, one form of domestic violence. ${ }^{36}$ Despite the Domestic Violence Elimination Law, does not regulate that a husband committed polygamous marriage automatically committing sexual violence, Article 1 (1) of the Domestic Violence Elimination Law, has recognized that any law causing physical, sexual, and psychological suffering is a domestic violence law. Therefore, polygamous marriage results in sexual misery or suffering for a wife can be said as sexual violence. However, the problem is there is also Law Number 1 of 1974 concerning on Marriage that allows a man to have more than one wife. It does not mean that the Government of Indonesia allows sexual violence through the Marriage Law, allowing a man to have more than one wife. What the Domestic Violence Elimination Law regulates regarding sexual violence is that it is a violation if it is bringing concrete misery or suffering that requires it to be evidenced through a criminal investigation. In terms of the protection of a victim of sexual violence, besides the recent Law of Domestic Violence Elimination, Law Number 31 of 2014 has regulated that sexual crime victims are entitled of being protected by the Witness and Victim Protection Agency. ${ }^{37}$ It may also cover the sexual violence

Moreover, Article 47 prohibits the Law ruled in Article 8 (b) of the Law, which is forcibly committing sexual violence towards women staying to have a sexual relationship with a person outside of the household for commercial purposes. For this violation of Article 8 (b), the minimum penalty of 4 years imprisonment and the maximum penalty of 12 years imprisonment to be imposed and the fine between Rp. 12.000.000 and Rp. 300.000 .000 can be imposed towards the violator. The Domestic Violence Elimination Law has not specifically legislated the kind of social services towards a woman as a victim of domestic violence. There is the fact that inadequate access to the services for them has caused them to hesitate to report or they disclose the perpetration. ${ }^{38}$ The Domestic Violence Elimination Law has severe punishments if sexual violence brings about serious effects. It is worded in Article 48 which regulates that if the violations mentioned in Articles 46 and 47 resulting in permanent wounds on

\footnotetext{
${ }^{35}$ Roikhatul Maghfiroh, "Kekerasan Seksual (Pemerkosaan) Dalam Rumah Tangga Sebagai Alasan Pengajuan Perceraian Dalam Tinjauan Hukum Islam Dan Hukum Positif," AlMazahib: Jurnal Pemikiran Hukum 7, no. 2 (2019): 239-49, http://ejournal.uinsuka.ac.id/syariah/almazahib/article/view/2205.

${ }^{36}$ Aisyah and Parker, "Problematic Conjugations: Women's Agency, Marriage and Domestic Violence in Indonesia."

37 Mahfud Mahfud, "Crime Victims Protection in Indonesia: An Analysis of the Recent Victim Protection Acts," Kertha Patrika 42, no. 2 (2020): 115-31, https://doi.org/10.24843/KP.2020.v42.i02.p02.

${ }^{38}$ Lauren Rumble et al., "Childhood Sexual Violence in Indonesia: A Systematic Review," Trauma, Violence, \& Abuse 21, no. 2 (2020): 284-99, https://doi.org/10.1177/1524838018767932.
} 
victims, psychological disease at least four weeks continuously or a year not continuously, death of the fetus, or reproduction organ damage, the minimum penalty of imprisonment is 5 years and a maximum penalty of imprisonment is 20 years or the fine between Rp. 25.000 .000 and Rp. 500.000 .000 .

\section{d. Household Negligence}

Article 49 of the Domestic Violence Elimination Law, has worded the penal sanction that can be imposed towards the perpetrator committing household negligence towards the household members mentioned in Article 9 of this Law. Article 49 provides that the law of household negligence towards household members that need to be taken care of or let them financially depended on the perpetrator by not allowing them to work to make them economically dependent on the perpetrator can be sentenced to 3 years imprisonment or the maximum fine of Rp. 15.000.000. This provision requires everyone who is by legal, approval, or agreement having an obligation to take care of the person must not commit household negligence or economic violence. Thus, a marriage is a relationship that bears a burden on a husband to take care of his wife. There is no boundary of household negligence in the Domestic Violence Elimination Law, towards a woman or a wife, but research shows that it can be not taking care of a wife and prohibiting a wife to work that is ruled in Article 9 (2) of this Law aiming at making a wife being dependent economically towards a husband. Since there is no limit to this kind of domestic violence towards a woman or a wife, it should be interpreted from Law Number 1 of 1974 concerning on Marriage.$^{39}$ However, it is also possible that the perpetration of household negligence as ruled in Article 49 can happen if the commission committed towards those who are not in a marriage relationship as legislated in Article 9 (2) of the Domestic Violence Elimination Law by prohibiting them to work inside or outside the household aiming at making them economically dependent upon the perpetrator or put them financially under the control of the perpetrator.

There are several forms of economic abuse or negligence in a household committed by a husband. These are namely; limiting a wife's spending on daily needs, not providing any economic support for a wife as a husband has another wife, and a husband being violent if a wife asking for money. These facts show that the husband is not only attempting to restrict and control a woman's access to economic resources but also a husband's refusal to take responsibility for financial deficiencies which can be seen when a wife asks

\footnotetext{
${ }^{39}$ Andrie Irawan, "Batasan Penelantaran Rumah Tangga Dalam Perspektif Hukum Kekerasan Dalam Rumah Tangga Dan Hukum Perkawinan Indonesia," Jurnal Hukum Responsif 7, no. 2 (2019): 100-109, http://jurnal.pancabudi.ac.id/index.php/hukumresponsif/article/view/735. 394
} 
for some money from the husband. ${ }^{40}$ It is the fact that a husband shifts his failure to provide financial support for his family on a woman and a husband is committing economic abuse or being violent towards his wife if she is reminding him about his inability to provide financial support for the family.

\section{Conclusion}

The Domestic Violence Elimination Law as the recent domestic violence legislation does not only prohibit violent laws committed in the household towards men, but also the violence committed against women in Indonesia. However, the main purpose of the promulgation of this Law is to protect women particularly as the making of this Law is a response to the CEDAW Convention ratification by the Government of the Republic Indonesia. This Law has recognized four types of domestic violence against women, namely physical violence, sexual violence, psychological violence, and negligence in the household. To recognize physical violence perpetration may be easier than the other forms of domestic violence towards women. Interestingly, marital rape has been worded, as sexual violence under this Law although it may be difficult to enforce its criminal sanction as sexual violence against women must be reported intentionally. It means that the perpetrator cannot be punished without a report from the victim. Meanwhile, polygamy marriage would be fall under sexual abuse or psychological violence towards women, but the Law does not limit in what circumstances it can criminalize the husband for such polygyny. The Law would be better implemented if there are clear boundaries of such blurred issues concerning domestic violence in Indonesia.

\section{References}

Afrianty, Dina. “Agents for Change: Local Women's Organizations and Domestic Violence in Indonesia." Bijdragen Tot de Taal- Land- En Volkenkunde / Journal of the Humanities and Social Sciences of Southeast Asia and Oceania 174, no. 1 (2018): 24-46. https://doi.org/10.1163/22134379-17401024.

Aisyah, Siti, and Lyn Parker. "Problematic Conjugations: Women's Agency,

Marriage and Domestic Violence in Indonesia." Asian Studies Review 38, no. 2 (2014): 205-23. https://doi.org/10.1080/10357823.2014.899312.

Alfitri, Alfitri. "Protecting Women from Domestic Violence: Islam, Family Law, and the State in Indonesia." Studia Islamika 27, no. 2 (2020): 273-307. https://doi.org/10.36712/sdi.v27i2.9408.

Arief, Hanafi. "Legal Protection Against Women Victims by The Indonesian

\footnotetext{
${ }^{40}$ Aisyah and Parker, "Problematic Conjugations: Women's Agency, Marriage and Domestic Violence in Indonesia."
} 
Domestic Violence Act 23, 2004." Sriwijaya Law Review 1, no. 1 (2017): 110-21. https://doi.org/10.28946/slrev.Vol1.Iss1.12.pp110121.

Bennett, Linda R., Sari Andajani-Sutjahjo, and Nurul I. Idrus. "Domestic Violence in Nusa Tenggara Barat, Indonesia: Married Women's Definitions and Experiences of Violence in the Home." The Asia Pacific Journal of Anthropology 12, no. 2 (2011): 146-63. https://doi.org/10.1080/14442213.2010.547514.

Drijber, Babette C., Udo JL Reijnders, and Manon Ceelen. "Male Victims of

Domestic Violence." Journal of Family Violence 28, no. 2 (2013): 173-78. https://doi.org/10.1007/s10896-012-9482-9.

Goodmark, Leigh S. "Should Domestic Violence Be Decriminalized?" Harvard Journal of Law \& Gender 40, no. 15 (2017): 53-113.

Hayati, Elli Nur, Maria Emmelin, and Malin Eriksson. "Challenges for a Local Service Agency to Address Domestic Violence-A Case Study from Rural Indonesia." Global Journal of Health Science 6, no. 6 (2014): 214-25. https://doi.org/10.5539/gjhs.v6n5p214.

Irawan, Andrie. "Batasan Penelantaran Rumah Tangga Dalam Perspektif Hukum Kekerasan Dalam Rumah Tangga Dan Hukum Perkawinan Indonesia." Jurnal Hukum Responsif 7, no. 2 (2019): 100-109. http://jurnal.pancabudi.ac.id/index.php/hukumresponsif/article/view/73 5.

Maghfiroh, Roikhatul. "Kekerasan Seksual (Pemerkosaan) Dalam Rumah Tangga Sebagai Alasan Pengajuan Perceraian Dalam Tinjauan Hukum Islam Dan Hukum Positif." Al-Mazahib: Jurnal Pemikiran Hukum 7, no. 2 (2019): 239-49. http://ejournal.uinsuka.ac.id/syariah/almazahib/article/view/2205.

Mahfud, Mahfud. "Crime Victims Protection in Indonesia: An Analysis of the Recent Victim Protection Acts." Kertha Patrika 42, no. 2 (2020): 115-31. https://doi.org/10.24843/KP.2020.v42.i02.p02.

McQuigg, Ronagh JAMcQuigg, Ronagh JA. "Domestic Violence as a Human Rights Issue: Rumor v. Italy." European Journal of International Law 26, no. 4 (2015): 1009-25. https://doi.org/10.1093/ejil/chv057.

Munir, Lily Zakiyah. "Domestic Violence in Indonesia." Muslim World Journal of Human Rights 2, no. 1 (2005): 1-37. https://doi.org/10.2202/1554-4419.1031.

Nur Hayati, Elli, Malin Eriksson, Mohammad Hakimi, Ulf Högberg, and Maria Emmelin. “Elastic Band Strategy': Women's Lived Experience of Coping with Domestic Violence in Rural Indonesia." Global Health Action 6, no. 1 (2013): 1-12. https://doi.org/10.3402/gha.v6i0.18894.

Perempuan, Komisi Nasional Anti Kekerasan Terhadap. "Instrumen Pemantauan Monev." Komnas Perempuan, 2021. https://komnasperempuan.go.id/instrumen-pemantauan- 
monevdetail/menemukenali-kekerasan-dalam-rumah-tangga-kdrt.

Purwanti, Ani, and Fajar Ahmad Setiawan. "The State of Policy of Anti

Domestic Violence During Covid-19 Pandemic in Indonesia."

Brawijaya Law Journal: Journal of Legal Studies 7, no. 2 (2020): 23854. https://doi.org/10.21776/ub.blj.2020.007.02.07.

Putra, I Gusti Ngurah Edi, Putu Erma Pradnyani, and Ni Wayan Putri

Larassita Parwangsa. "Vulnerability to Domestic Physical Violence among Married Women in Indonesia." Journal of Health Research 33, no. 2 (2019): 90-105. https://doi.org/10.1108/JHR-06-2018-0018.

Riggins, Leah. "Criminalizing Marital Rape in Indonesia." Boston College Third World Law Journal 24, no. 2 (2004): 421-26. https://lawdigitalcommons.bc.edu/twlj/vol24/iss2/6.

Rofiah, Nur. "Kekerasan Dalam Rumah Tangga Dalam Perspektif Islam." Wawasan: Jurnal Ilmiah Agama Dan Sosial Budaya 2, no. 1 (2017): 31-44. https://doi.org/10.15575/jw.v2i1.829.

Rumble, Lauren, Ryan Fajar Febrianto, Melania Niken Larasati, Carolyn Hamilton, Ben Mathews, and Michael P. Dunne. "Childhood Sexual Violence in Indonesia: A Systematic Review." Trauma, Violence, \& $\begin{array}{llll}\text { Abuse } & 21, & \text { no. 284-99. }\end{array}$ https://doi.org/10.1177/1524838018767932.

Sagar, Rajesh, and Gagan Hans. "Domestic Violence and Mental Health." Journal of Mental Health and Human Behaviour 23, no. 1 (2018): 2-3. https://doi.org/10.4103/0971-8990.244924.

Šimonović, Dubravka. "Global and Regional Standards on Violence Against Women: The Evolution and Synergy of the CEDAW and Istanbul Conventions." Human Rights Quarterly 26, no. 3 (2014): 590-606. http://www.jstor.org/stable/24518259.

Sitompul, Roswita, Alesyanti, and Muhammad Ridwan. "Domestic Violence as Initiated by Batak Culture in East Medan, Indonesia." Journal of Human Behavior in the Social Environment 30, no. 7 (2020): 835-42. https://doi.org/10.1080/10911359.2020.1750526.

Susila, Muhammad Endriyo. "Islamic Perspective on Marital Rape." Jurnal Media Hukum 20, no. 2 (2013): 317-32. https://journal.umy.ac.id/index.php/jmh/article/view/271.

Venning, Philippa. "Marrying Contested Approaches: Empowerment and the Imposition of International Principles: Domestic Violence Case Resolution in Indonesia." The Journal of Development Studies 46, no. 3 (2010): 397-416. https://doi.org/10.1080/00220380903002913. 
